OPEN ACCESS

Edited by:

Jesús Mercado-Blanco, Consejo Superior de Investigaciones

Cientificas (CSIC), Spain

Reviewed by:

Tomislav Cernava,

Graz University of Technology, Austria

Aurélien Bailly,

University of Zurich, Switzerland

*Correspondence: Choong-Min Ryu cmryu@kribb.re.kr

Specialty section: This article was submitted to Plant Microbe Interactions, a section of the journal

Frontiers in Plant Science

Received: 24 November 2017 Accepted: 16 January 2018

Published: 22 February 2018

Citation:

Kong HG, Shin TS, Kim TH and Ryu C-M (2018) Stereoisomers of the

Bacterial Volatile Compound

2,3-Butanediol Differently Elicit

Systemic Defense Responses

of Pepper against Multiple Viruses

in the Field. Front. Plant Sci. 9:90.

doi: 10.3389/fpls.2018.00090

\section{Stereoisomers of the Bacterial Volatile Compound 2,3-Butanediol Differently Elicit Systemic Defense Responses of Pepper against Multiple Viruses in the Field}

\author{
Hyun G. Kong ${ }^{1}$, Teak S. Shin' ${ }^{2}$ Tae H. Kim ${ }^{2}$ and Choong-Min Ryu ${ }^{1 *}$ \\ ${ }^{1}$ Molecular Phytobacteriology Laboratory, Infectious Disease Research Center, Korea Research Institute of Bioscience and \\ Biotechnology, Daejeon, South Korea, ${ }^{2}$ Crop Protection R\&D Center, Farm Hannong Co., Ltd., Nonsan-si, South Korea
}

The volatile compound 2,3-butanediol, which is produced by certain strains of rootassociated bacteria, consists of three stereoisomers, namely, two enantiomers (2R,3Rand 2S,3S-butanediol) and one meso compound (2R,3S-butanediol). The ability of 2,3-butanediol to induce plant resistance against pathogenic fungi and bacteria has been investigated; however, little is known about its effects on induced resistance against viruses in plants. To investigate the effects of 2,3-butanediol on plant systemic defense against viruses, we evaluated the disease control capacity of each of its three stereoisomers in pepper. Specifically, we investigated the optimal concentration of 2,3butanediol to use for disease control against Cucumber mosaic virus and Tobacco mosaic virus in the greenhouse and examined the effects of drench application of these compounds in the field. In the field trial, treatment with 2R,3R-butanediol and 2R,3Sbutanediol significantly reduced the incidence of naturally occurring viruses compared with 2S,3S-butanediol and control treatments. In addition, 2R,3R-butanediol treatment induced the expression of plant defense marker genes in the salicylic acid, jasmonic acid, and ethylene signaling pathways to levels similar to those of the benzothiadiazoletreated positive control. This study reports the first field trial showing that specific stereoisomers of 2,3-butanediol trigger plant immunity against multiple viruses.

Keywords: bacterial volatile compound, 2,3-butanediol, plant viral disease, ISR, pepper

\section{INTRODUCTION}

A wide range of plant pathogens cause diseases in crops, leading to serious losses in yields, increased labor and costs, and human health problems caused by the use of harmful chemicals (Agrios, 2005; Strange and Scott, 2005; Lamberth et al., 2013). Among plant diseases, the incidence of viral diseases has been increasing yearly due to global warming, which is causing serious problems because there are currently no practical control methods for these diseases (Mandadi and Scholthof, 2013; Guerret et al., 2016; Jones, 2017). To date, the control of viral disease has primarily involved monitoring and chemical management of vectors that mediate disease progression, as well 
as virus resistance-based breeding and transgenic-based gene technology (Perring et al., 1999; Kang et al., 2005; Hashimoto et al., 2016; Khalid et al., 2017). However, the use of these technologies is limited due to environmental safety issues and the large amount of time it takes to apply them to the field (Agrios, 2005; Valkonen, 2015).

Many studies have focused on the use of induced resistance, i.e., systemic acquired resistance (SAR) and induced systemic resistance (ISR), against a variety of viruses as an alternate method for plant virus control. In particular, SAR against viral diseases in plants can be induced by weakened viruses, and plants can be protected from various viral diseases through systemic or localized viral infection (Ross, 1961; Ryals et al., 1994). However, the use of viruses to induce SAR is limited by treatment difficulties and the low success rate of inducible resistance in plants. As an alternative, microbes (pathogenic and beneficial bacteria) and chemicals have been used to induce plant resistance. However, it is difficult to apply pathogens in order to elicit plant resistance in the field, and some chemicals have significant negative effects on vegetative and generative growth (Ross, 1961; Tally et al., 1999; Kloepper et al., 2004a). Therefore, an increasing number of studies have focused on the induction of resistance in crops without perturbing their growth using plant growth-promoting rhizobacteria (PGPR) (Raupach et al., 1996; Zehnder et al., 2000; Zehnder et al., 2001; Murphy et al., 2003; Ryu et al., 2004). The application of Pseudomonas fluorescens CHAO, Pseudomonas putida 89B61, and Serratia marcescens 90166 reduced the development of symptoms caused by Tobacco necrosis virus or Cucumber mosaic virus (CMV) in cucumber and tomato via eliciting ISR (Maurhofer et al., 1994; Raupach et al., 1996; Zehnder et al., 2000). Spraying of Bacillus amyloliquefaciens strain 5B6 (isolated from a cherry tree leaf) was recently reported to delay the development of symptoms caused by CMV in pepper (Lee and Ryu, 2016). To obtain PGPR-mediated ISR in the field, the activity and population instability of the treated bacteria are important issues. To overcome the disadvantages of microbial instability in the field, scientists have attempted to identify bacterial determinants, such as lipopolysaccharides, siderophores, and bacterial metabolites, with similar effects in vitro and in greenhouse experiments (Leeman et al., 1995; Duijff et al., 1997; Ongena et al., 2005; Ryu et al., 2013).

B. amyloliquefaciens strain IN937a was recently shown to stimulate systemic resistance due to the release of bacterial volatile compounds (BVCs) (Kloepper et al., 2004b; Ryu et al., 2004; Choi et al., 2014). Treatment with BVCs from PGPR reduced symptom development and CMV accumulation in pepper seedlings (Song et al., 2013; Choi et al., 2014). BVCs are important chemicals in plant virus control because they can affect plant resistance and can be applied on a wide range of scales (Kesselmeier and Staudt, 1999; Ryu et al., 2004; Kai et al., 2009).

One such BVC, 2,3-butanediol, is produced by various bacteria such as Bacillus spp., Aerobacter spp., and Klebsiella spp. (Barrett et al., 1983; Voloch et al., 1985; Ryu et al., 2004; Kopke et al., 2011). This compound is used in the manufacture of synthetic industrial products, aviation fuel, explosives, plasticizers, and pharmaceuticals (Gupta et al., 2005).
Treatment with 2,3-butanediol has beneficial effects on plants, such as growth promotion and the induction of systemic resistance in Arabidopsis thaliana and tobacco (Ryu et al., 2003, 2004; Han et al., 2006). Both 2,3-butanediol and 2-butanol affect plant physiology, promote growth, and induce defense against the insect pest Spodoptera littoralis in maize (Zea mays) (D'Alessandro et al., 2014). However, little is known about the efficacy and applicability of other 2,3-butanediol isomers to plants to control plant viruses.

In this study, we evaluated the efficacy of bacterial volatiles for managing common, economically important viral diseases of pepper in South Korea under greenhouse and field conditions. Since the effect of 2,3-butanediol on induced resistance against viruses has not yet been studied, we investigated its effect on multiple viral diseases. First, we determined the optimal concentration of 2,3-butanediol to use to control CMV and Tobacco mosaic virus (TMV) under greenhouse conditions. In addition, we examined the effect of 2,3-butanediol isomers on induced resistance against TMV. We then examined the use of two enantiomers (2R,3R and $2 \mathrm{~S}, 3 \mathrm{~S}$-butanediol) and one meso compound (2R,3S-butanediol) in the field to control viral diseases, which were alleviated by these treatments compared with the control. We measured virus levels in plants using five representative pepper viruses in South Korea, including CMV, TMV, Pepper mottle virus (PepMoV), Tomato yellow leaf curl virus (TYLCV), and Tomato spotted wilt virus (TSWV), by qRT-PCR using specific primers. We confirmed the induction of plant defense systems by examining the expression of molecular markers of induced resistance, including genes related to/encoding Capsicum annuum pathogenesis-related 4 (CaPR4), Ca chitinase 2 (CaChi2), Ca phenylalanine-I ammonia-lyase (CaPAL), CaSAR8.2, Ca 1-aminocyclopropane-1-carboxylic acid oxidase (CaACC), and Ca proteinase inhibitor 2 (CaPIN2). Treatment with 2R,3R- and 2R,3S-butanediol reduced the severity of diseases caused by naturally occurring plant viruses and increased the yield of mature pepper fruits. Collectively, 2,3-butanediol treatments had different effects on inducing systemic resistance and viral suppression, depending on the isomer. This is the first report on the use of different isomers of BVCs to induce resistance to viral pathogens in pepper.

\section{MATERIALS AND METHODS}

\section{Greenhouse Trials}

The induction of resistance against CMV and TMV by 2,3-butanediol isomers (Sigma-Aldrich Corp., Korea; Lot number 237639 (2R,3R-), 300349 (2S,3S-), 361461 (2R,3S-) was investigated in the greenhouse. Pepper (Capsicum annum L. cv. Bukwang) seeds were surface-sterilized with $6 \%$ sodium hypochlorite, washed four times with sterile distilled water, and then maintained on Murashige and Skoog agar medium (Duchefa, Haarlem, Netherlands) at $25^{\circ} \mathrm{C}$ for 3 days until germination. Germinated seeds were then transplanted into soil-less medium (Punong Horticulture Nursery Media LOW, Punong Co. Ltd., Gyeongju, Korea). Seedlings were grown in 
controlled conditions at $25 \pm 2{ }^{\circ} \mathrm{C}$ under fluorescent light with an intensity of approximately 7,000 lux and a $12 \mathrm{~h} / 12 \mathrm{~h}$ day/night cycle, and were then transferred to the KRIBB greenhouse facility in Daejeon, South Korea.

2,3-Butanediol was prepared at concentrations of 1,5 , and $10 \mathrm{mM}$. Four-week-old pepper seedlings were drenched with $20 \mathrm{~mL}$ of each diluted solution of 2,3-butanediol. Alternatively, seedlings were treated with $1 \mathrm{mM}$ benzothiadiazole $(\mathrm{BTH}$; Syngenta, Durham, NC, United States) and water as positive and negative controls, respectively.

CMV and TMV were maintained in Nicotiana tabacum by mechanical passage in a temperature-controlled greenhouse. The virus inoculum used throughout the experiments consisted of systemically infected N. tabacum tissue ground in $50 \mathrm{mM}$ potassium phosphate buffer, $\mathrm{pH} 7.0$, containing $10 \mathrm{mM}$ sodium sulfite ( $1 \mathrm{~g}$ of tissue: $10 \mathrm{ml}$ of buffer). All tissues were chilled prior to use and maintained on ice during inoculation.

The primary leaves were rub-inoculated with CMV or TMV 7 days after treatment with 2,3-butanediol, BTH, or water (control). 'Mock' inoculated plants were rub-inoculated with $50 \mathrm{mM}$ potassium phosphate buffer. The experiment was repeated three times with 10 replications per experiment. Virus quantification was performed via qRT-PCR as described below at 2 weeks after virus inoculation.

\section{Field Trial}

The field trial was conducted in Geumsan-gun, Chungcheongnam-do, South Korea $\left(36^{\circ} 35^{\prime} \quad 32.27^{\prime \prime}\right.$ North, $127^{\circ} 30^{\prime} 34.75^{\prime \prime}$ East), where plants are affected by multiple viral diseases each year, in mid-April of 2016 and 2017. For the field study, all necessary permits were obtained from the owners of private lands. Pepper seedlings (Capsicum annum L. cv. Bukwang) were transplanted at a distance of $30 \mathrm{~cm}$. Before transplanting, the furrows were covered with black polyethylene plastic film to prevent weed problems. To test induced resistance under field conditions, 1-month-old seedlings were drenched with $100 \mathrm{ml}$ per plant of $1 \mathrm{mM} \mathrm{2,3-butanediol} \mathrm{isomers} \mathrm{(2R,3R}$ form, 2S,3S form, and 2R,3S form) (Sigma-Aldrich Corp., Korea) and $1 \mathrm{mM}$ BTH solution three times per month. The same volume of sterilized water was used as a negative control. Each treatment was replicated five times in a completely randomized block design and consisted of 20 plants per treatment.

\section{Measurement of Pepper Fruit Yields}

To investigate whether 2,3-butanediol isomers and $\mathrm{BTH}$ influence pepper fruit yields under field conditions compared with the water control, yields were measured 100 days post-treatment (dpt). Red-colored fruits (only) were harvested twice from mid-August to the end of August, depending on the growing season. Total yield (g/plant) per treatment was estimated, and the total fruit weight per plant was calculated for each harvest time. In addition, the number of fruits per plant was recorded for each harvest, and the total harvest was then calculated as the number of fruits/plant.

\section{Diagnosis of Viral Diseases}

To evaluate plant virus levels in the field, 30 leaves per replication were randomly sampled 90 days after the application of 2,3butanediol isomers and BTH. The leaves were immediately frozen in liquid nitrogen for total RNA extraction. Total RNA was isolated from the leaves using Tri reagent (Molecular Research Inc., Cincinnati, OH, United States) according to the manufacturer's instructions and as described in our previous study (Lee et al., 2017). First-strand cDNA synthesis was performed with $2 \mu \mathrm{g}$ of DNase-treated total RNA, oligo$\mathrm{dT}$ primers, and Moloney murine leukemia virus reverse transcriptase (Enzynomics, Daejeon, Korea). The qRT-PCR assays consisted of $\mathrm{cDNA}, \mathrm{iQ}^{\mathrm{TM}} \mathrm{SYBR}^{\circledR}$ Green Supermix (BioRad Inc., Hercules, CA, United States), and $10 \mathrm{pM}$ of each primer. The cycling parameters were as follows: initial polymerase activation for $10 \mathrm{~min}$ at $95^{\circ} \mathrm{C}$; followed by 40 cycles of $30 \mathrm{~s}$ at $95^{\circ} \mathrm{C}, 60 \mathrm{~s}$ at $55^{\circ} \mathrm{C}$, and $30 \mathrm{~s}$ at $72^{\circ} \mathrm{C}$. The identification of plant viruses as CMV, TMV, PepMoV, TYLCV, or TSWV was performed using the specific primer pairs shown in Table 1. CaUBQ (ubiquitin) was used as a loading control to ensure

TABLE 1 | Primer sets used for the amplification of plant viruses and expression analysis of defense-related genes in this study.

\begin{tabular}{|c|c|c|}
\hline & Primer & Sequence $\left(5^{\prime}-3^{\prime}\right)$ \\
\hline \multirow{10}{*}{$\begin{array}{l}\text { Plant } \\
\text { pathogenic } \\
\text { virus }\end{array}$} & CMV CP Forward & 5'-CGTTGCCGCTATCTCTGCTAT-3' \\
\hline & CMV CP Reverse & 5'-GGATGCTGCATACTGACAAACC-3' \\
\hline & TMV Forward & 5'-ATGTCTTACAGTATCACTAC-3' \\
\hline & TMV Reverse & 5'-TCAAGTTGCAGGACCAGAGG-3' \\
\hline & PepMoV Forward & 5'-CAAGCAAGGGTATGCATGT-3' \\
\hline & PepMoV Reverse & 5'-AAGATCAGACACATGGA-3' \\
\hline & TYLCV Forward & 5'-CGCCCGCCTCGAAGGTTC-3' \\
\hline & TYLCV Reverse & 5'-TCGTCGCTTGTTGTGCCTTG-3' \\
\hline & TSWV Forward & 5'-ATGTCTAAGGTTAAGCTCAC-3' \\
\hline & TSWV Reverse & 5'-TCAAGCAAGTTCTGCGAGTT-3' \\
\hline \multirow{20}{*}{$\begin{array}{l}\text { Plant } \\
\text { defense-related } \\
\text { gene }\end{array}$} & CaUBQ Forward & 5'-GCACAAGCACAAGAAGGTTAAG-3' \\
\hline & CaUBQ Reverse & 5'-GCACCACACTCAGCATTAGGA-3' \\
\hline & CaPR1 Forward & 5'-ACTTGCAATTATGATCCACC-3' \\
\hline & CaPR1 Reverse & 5'-ACTCCAGTTACTGCACCATT-3' \\
\hline & CaPR2 Forward & $5^{\prime}$-गाTAGCTATGCTGGTAATCCGCG-3' \\
\hline & CaPR2 Reverse & 5'-AAACCATGAGGACCAACAAAAGCG-3' \\
\hline & CaPR4 Forward & 5'-AACTGGGATTGAGAACTGCCAGC-3' \\
\hline & CaPR4 Reverse & 5'-ATCCAAGGTACATATAGAGCTTCC-3' \\
\hline & CaPIN2 Forward & 5'-TGGGACTTCATTGTGAAGGAGAG-3' \\
\hline & CaPIN2 Reverse & 5'-GACACAGTGAATAGGCAATATTTGG-3' \\
\hline & CaPAL Forward & 5'-ATTCGCGCTGCAACTAAGAT-3' \\
\hline & CaPAL Reverse & 5'-CACCGTGTAAGGCCTTGTTा-3' \\
\hline & CaACC Forward & 5'-AGTGGCCTTCAACTCСTCAА-3' \\
\hline & CaACC Reverse & 5'-TTCCGTTTGTGATCACCTCA-3' \\
\hline & CaSAR8.2 Forward & 5'-TAGTGAGACTAAGAAAGTTGGACG-3' \\
\hline & CaSAR8.2 Reverse & 5'-AAGAGTGCATGCAGTATCACAAAG-3' \\
\hline & CaChi2 Forward & 5'-ATTGGACGATGGAAGCCATCACCAG-3' \\
\hline & CaChi2 Reverse & 5'-ATATTCCGAATGTCTAAAGTGGTAC-3' \\
\hline & CaActin Forward & 5'-CACTGAAGCACCCTTGAACCC-3' \\
\hline & CaActin Reverse & 5'-GAGACAACACCGCCTGAATAGC-3' \\
\hline
\end{tabular}


that equal amounts of RNA were used in each assay. Relative transcript levels were normalized with respect to CaUBQ mRNA levels and calculated using the $2^{-\Delta \Delta \mathrm{C}_{\mathrm{T}}}$ method. Standard error of mean values among replicates were calculated using Bio-Rad manager (version 2.1) (Bio-Rad CFX Connect).

\section{Assessment of Defense-Priming Gene Expression}

To analyze the expression of defense-priming genes, the expression of candidate priming genes was analyzed using the primers shown in Table 1 (Yang et al., 2009, 2011; Song et al., 2013). The expression of defense-priming genes in pepper leaves was analyzed using the same leaves sample as the assay of viral disease. As a control to ensure that equal amounts of RNA were analyzed in each experiment, relative RNA levels were calibrated and normalized to the level of CaActin mRNA (GenBank accession no. AY572427).

\section{Statistical Analysis}

The experimental data sets were subjected to analysis of variance using JMP software ver. 4.0 (SAS Institute Inc., Cary, NC, United States ${ }^{1}$ ). The significance of differences among treatments was determined based on the magnitude of the $F$ value at $P=0.05$. When a significant $F$ value was obtained for the treatments, separation of means was accomplished using Fisher's protected least-significant difference (LSD) at $P=0.05$.

\section{RESULTS}

\section{Optimization of 2,3-Butanediol Levels to Elicit Induced Resistance under Greenhouse Conditions}

In our previous study (Choi et al., 2014), we found that the use of $1 \mathrm{mM}$ 2,3-butanediol reduced the severity of bacterial spot caused by Xanthomoas axonopodis pv. vesicatora in pepper. However, it was not clear whether this compound induces resistance activity against plant viral pathogens. To evaluate whether 2,3-butanediol induces plant immunity against CMV and TMV under greenhouse conditions, we quantified the viruses 2 weeks after infection in the greenhouse. After TMV inoculation, we observed yellowing caused by the virus in the leaves of the control plants, whereas no symptoms were observed in the leaves of plants under 2,3-butanediol treatment (Figure 1A). In addition, the quantitative value of the virus (i.e., the relative gene expression level compared with $C a U B Q$ ) in the 2,3-butanediol treatment group was 0.1 , which was dramatically less than that of the control, at 16.25 (Figure 1B). Furthermore, to determine the minimum concentration of 2,3-butanediol needed, we examined the effect of 10,5, and $1 \mathrm{mM}$ 2,3-butanediol on CMV and TMV. Based on the quantification of CMV, there was no statistically significant difference among the 10,5 , and $1 \mathrm{mM}$ 2,3-butanediol treatments, with relative gene expression levels of $1.07,1.67$, and 1.69 , respectively; these values were three

${ }^{1}$ www.sas.com times less than the control (3.45) under all treatments. CMV levels were lowest after BTH treatment, at 0.63 (Figure 1B). The relative gene expression levels of TMV were $0.52,0.54$, and 1.06 under 10,5, and $1 \mathrm{mM}$ 2,3-butanediol treatment, respectively. Therefore, the concentration of virus was highest under $1 \mathrm{mM}$ 2,3-butanediol treatment, but there was no statistically significant difference among treatments. Under all treatments, CMV levels were significantly lower than those in the control. Under BTH treatment, the relative gene expression level of CMV was 0.68 , which was not significantly different from that detected under $1 \mathrm{mM}$ 2,3-butanediol treatment, the lowest concentration of this compound tested (Figure 1B). Therefore, the minimum effective concentration of 2,3-butanediol was $1 \mathrm{mM}(P<0.05, n=10)$, which was used in subsequent experiments.

\section{Assessment of the Protective Effects of 2,3-Butanediol against Viral Diseases under Field Conditions}

To evaluate virus resistance under field conditions in 2016, we treated field-grown pepper plants with 2,3-butanediol three times at 1 month intervals. We sampled leaves at 90 days after planting and performed quantitative analysis of five viruses: CMV, PepMoV, TMV, TSWV, and TYLCV. In the water-treated control, the five viruses (CMV, PepMoV, TMV, TSWV, and TYLCV) were detected at levels of 1.00, 5.38, 4.87, 5.38 , and 6.53 , respectively. Plants treated with 2,3-butanediol had viral levels of $0.41,0.06$, and 0.00 for CMV, TMV, and TYLCV, respectively, which did not significantly differ from the values obtained under BTH treatment $(0.33,0.36$, and 0.06 , respectively). Under 2,3-butanediol treatment, PepMoV and TSWV were detected at levels of 0.53 and 0.00 , respectively, which were lower than the levels detected under BTH treatment (3.08 and 1.36, respectively). Therefore, 2,3-butanediol can be successfully used to control various viruses under field conditions (Figures 2A,B).

To investigate the effect of 2,3-butanediol on red pepper fruit yields as well as the ability of the treatment to control viruses, we examined fruit yield in 2017. For the yield measurements, only red pepper was harvested in the second round, and the weight and number of fruits were measured. In the field experiment, the number of fruits did not significantly differ between the treatments; however, fruit weight per plant was $113.7 \mathrm{~g}$ upon 2,3butanediol treatment, an increase of 1.7 -fold compared with the control value of $67.2 \mathrm{~g}$ (Figure 2C).

Previous studies showed that viral suppression in plants is caused by the immune response (Mandadi and Scholthof, 2013). Therefore, in the current study, we investigated the mechanism underlying viral suppression in response to 2,3butanediol treatment by examining the expression of genes related to jasmonic acid (JA), salicylic acid (SA), and ethylene (ET) biosynthesis and signaling, as these plant hormones play a central role in the regulation of plant immune responses. The specific genes in the JA, SA, and ET pathways that we examined were CaPAL (SA), CaPIN2 (JA), CaChi2 (JA), CaSAR8.2 (SA), $\mathrm{CaACC}$ (ET), and CaPR4 (SA and JA). The relative expression levels of these genes in response to 2,3-butanediol treatment 
A
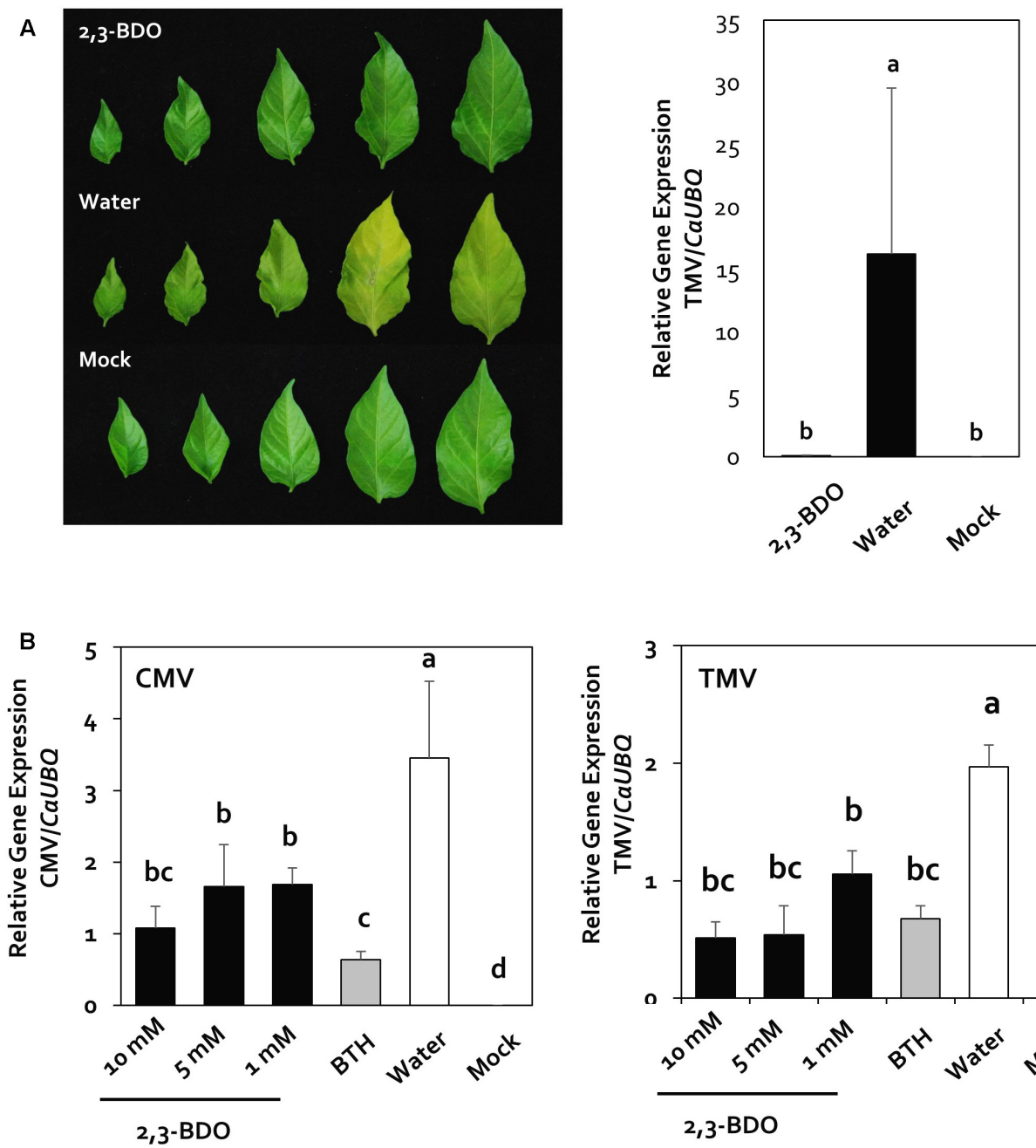

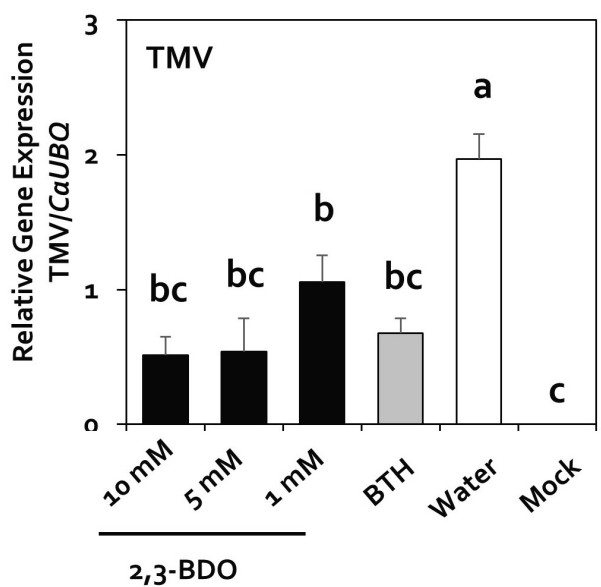

FIGURE 1 | Disease suppression of rub-inoculated viruses by drench application of 2,3-butanediol (2,3-BDO). (A) Disease symptoms caused by rub-inoculated Cucumber mosaic virus (CMV) were evaluated 2 weeks post-inoculation, and the induction of resistance against Tobacco mosaic virus (TMV) by 2,3-BDO was validated in the greenhouse. (B) Validation of the induction of resistance against CMV and TMV by treatment with three concentrations of 2,3-BDO in the greenhouse. Expression of viral-specific genes was measured 2 weeks after treatment of pepper plants with 1, 5, and 10 mM 2,3-BDO, 1 mM benzothiadiazole $(\mathrm{BTH})$, and water. Bars represent mean \pm SEM $(n=10)$. The housekeeping gene CaUBQ was used as a reference in $\mathrm{qPCR}$.

(compared with CaActin) were 1.46, 6.98, 1.00, 0.69, 0.66, and 0.41 , with increases of 46.4-, 3.3-, 10-, 5.2-, 1.7-, and 2.8fold, respectively, compared with the control (Figure 3). In particular, CaPIN2 and CaPR4 were more highly upregulated by 2,3-butanediol than by BTH treatment (Figure 3 ). Taken together, these results indicate that 2,3-butanediol induces the expression of plant defense marker genes in pepper, which could be associated with the induction of three major defense hormone signaling pathways, the SA, ET, and JA pathways, in these plants.

\section{Effect of 2,3-Butanediol Isomers on Induced Resistance against Naturally Occurring Viral Diseases}

In the natural ecosystem, microorganisms can produce three 2,3-butanediol isomers, i.e., the $\mathrm{R}$ form (2R,3R-butanediol),
$\mathrm{S}$ form (2S,3S-butanediol), and meso form (2R,3S-butanediol) depending on the species (Herold et al., 1995; Celińska and Grajek, 2009; Ji et al., 2011; Kandasamy et al., 2016). After the first year of greenhouse and field trials, we investigated whether the different isomers of 2,3-butanediol affect ISR. Treatment with 2,3-butanediol has an effect on virus control through increasing plant immunity. Therefore, we investigated the effects of the other isoforms of 2,3-butanediol in a second field experiment in 2016. We performed a quantitative assay of pepper viruses using the same five viruses as in the first field experiment but failed to detect TYLCV in the second field experiment. Treatment with 2R,3R-butanediol ( $\mathrm{R}$ form) led to a 2.8-, 689.7, 122.9-, and 25.9-fold decrease in CMV, TMV, PepMoV, and TSWV levels, respectively. Compared with 2R,3R-butanediol, the effect of 2R,3S-butanediol (meso form) treatment on these four viruses did not significantly differ from that of treatment 
A
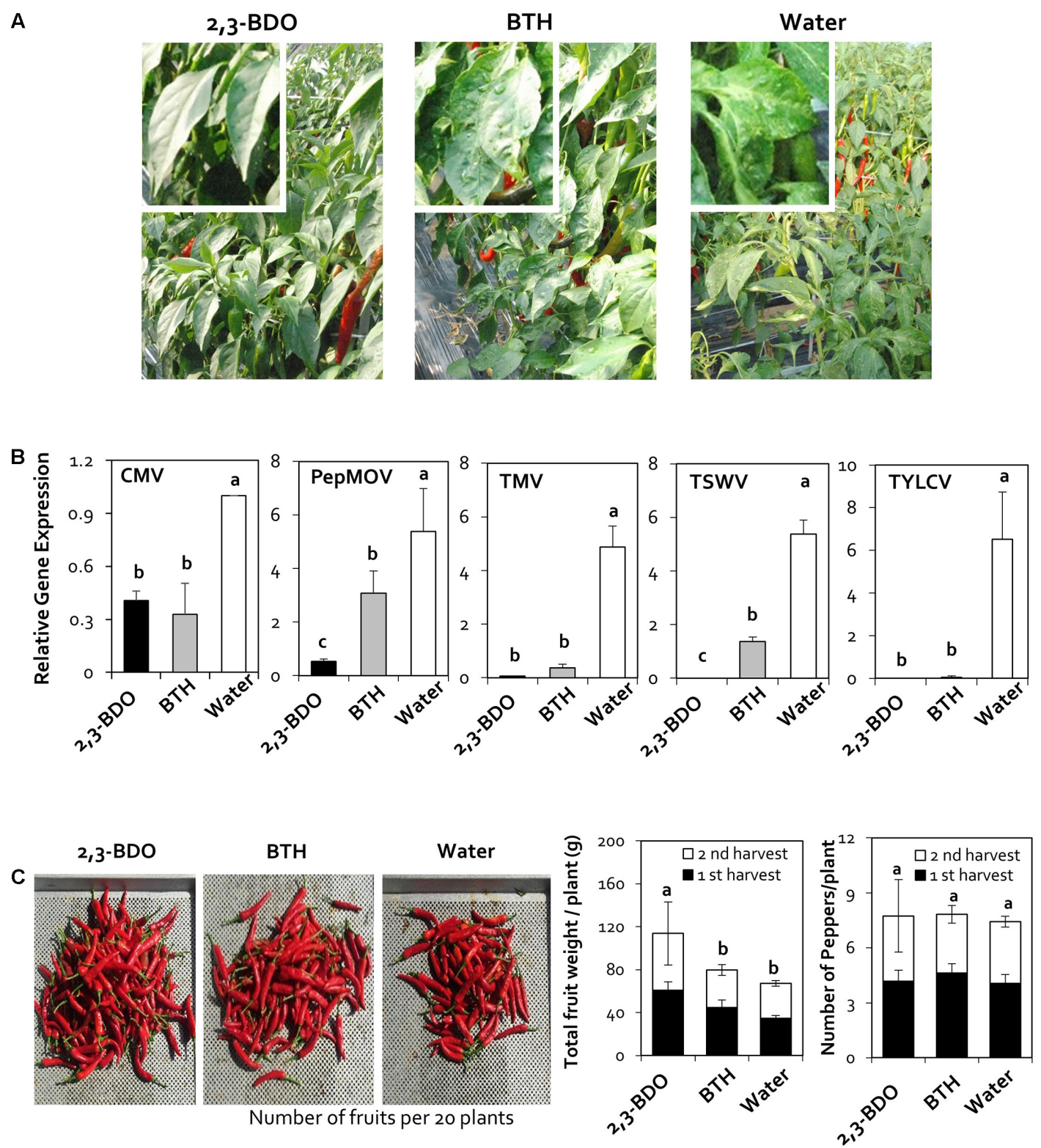

FIGURE 2 | Disease suppression of naturally occurring viruses by treatment with 2,3-butanediol (2,3-BDO). (A) Disease symptoms caused by naturally occurring viruses were evaluated at 90 days post-transplantation (dpt). (B) The induction of resistance against Cucumber mosaic virus (CMV), Pepper mottle virus (PepMoV), Tobacco mosaic virus (TMV), Tomato spotted wilt virus (TSWV), and Tomato yellow leaf curl virus (TYLCV) by application of 2,3-BDO was evaluated at 90 dpt in the field. Bars represent mean \pm SEM $(n=100)$. The housekeeping gene CaUBQ was used as a reference in qPCR. (C) Fruit fresh weight per plant and the fruit yield of 20 plants treated with 2,3-BDO, benzothiadiazole (BTH), and water were assessed at 100 dpt. Different letters indicate statistically significant differences $(P=0.05)$. Error bars represent mean \pm SEM.

with the other forms of 2,3-butanediol and BTH (Figure 4A). Plants treated with 2S,3S-butanediol (S form) showed a 9.2-fold decrease in TSWV levels compared with the control, which was not significantly different from the other treatments. However, under this treatment, the levels of CMV, TMV, and PepMoV were reduced by only 1.3-, 1.4-, and 1.7-fold, making 2S,3S-butanediol less effective than the other forms of 2,3-butanediol and BTH (Figure 4A). Therefore, the effects of the $\mathrm{R}$ form and meso form of 2,3-butanediol were similar to that of BTH treatment, whereas the $\mathrm{S}$ form of 2,3-butanediol had less of an effect than the other isomers.

To confirm the effects of these compounds, we investigated the expression of the plant immunity genes by qRT-PCR. Under 2R,3R-butanediol treatment, CaPIN2, CaPR1, CaChi2, CaPAL, CaSAR8.2, and CaPR4 were upregulated 2.9-, 15.7, 2.1-, 2.4-, 54.8-, and 1.7-fold, respectively, compared with water treatment (Figure 5). Under 2R,3R-butanediol treatment, the expression levels of these six genes were the highest 

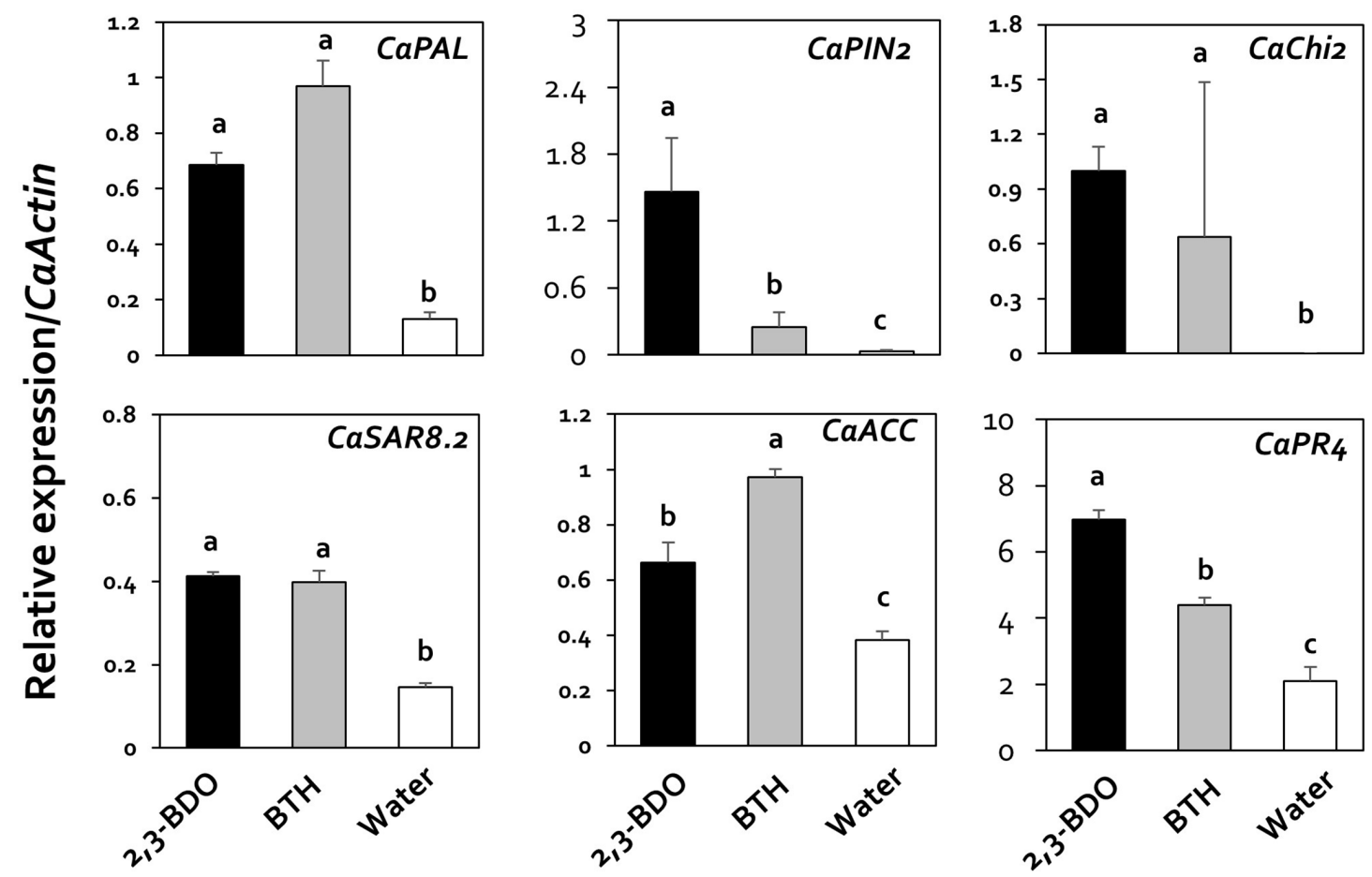

FIGURE 3 | Induction of pepper defense-related gene expression by 2,3-butanediol under field conditions. Quantification of the expression of marker genes of the salicylic acid (CaPAL, CaPR4, and CaSAR8.2), ethylene (CaACC), and jasmonic acid (CaPIN2, CaPR4, and CaChi2) signaling pathways in plants treated with 1 mM 2,3-butanediol, $1 \mathrm{mM}$ benzothiadiazole (BTH), and water. The housekeeping gene CaActin was used for normalization. Different letters within panels indicate significant differences between treatments according to LSD at a significance level of $P<0.05$. Error bars represent mean \pm SEM. Sample size: $n=100$ plants per treatment in 2016.

among 2,3-butanediol isomer treatments, with no significant difference from BTH treatment (Figure 5). The expression levels of CaPAL and CaSAR8.2 under 2R,3S-butanediol treatment were 0.7 and 0.2 , respectively, i.e., 1.7 - and 12.5 -times that of the water-treated control. However, these levels were lower than those measured under 2R,3R-butanediol and BTH treatments (Figure 5). By contrast, in plants treated with 2S,3S-butanediol, the expression levels of these genes did not significantly differ from those detected in the water-treated control (Figure 5).

Therefore, the decrease in virus levels detected under $2 \mathrm{R}, 3 \mathrm{R}-$ butanediol and BTH treatment was confirmed by the expression patterns of the plant defense genes.

\section{Measurement of Pepper Fruit Yields}

To investigate the effects of 2,3-butanediol isomers on red pepper fruit yields as well as the ability of the treatment to control viruses, we examined fruit yield in 2017. For the yield measurements, only red pepper was harvested in the second round, and the weight and number of fruits were measured. When we measured the yield of red pepper fruit in response to isomer treatment in the field in 2017, the number of fruits per plant was 7,6, and 7 per plant for plants treated with the R, S, and meso form of 2,3-butanediol, respectively, which was significantly higher than that of the BTH-treated group (3) and the control (4). The fruit weight was 116.8, 94.7, and
$117 \mathrm{~g}$ in plants treated with the R, S, and meso forms of 2,3butanediol, respectively, which was significantly higher than in plants treated with the BTH (40 g) and control (66 g) treatments (Figure 4B).

Based on the results of the 2 year field experiments, the $\mathrm{R}$ form of 2,3-butanediol is effective in controlling plant viral diseases and increasing the yields of red pepper fruit. These results are important for the practical application of volatile substances produced by microorganisms under field conditions. In addition, this is the first report that different 2,3-butanediol isomers have different effects on the control of plant viruses under field conditions.

\section{DISCUSSION}

Our study demonstrates that drench application of the BVC 2,3butanediol to roots induces plant systemic defense responses in pepper resulting in the reduced accumulation of viruses in leaves. In addition, we found that treating plants with different isomeric compounds of 2,3-butanediol had different effects on inducing plant immunity, depending on the structure of the bacterialderived volatile substance. This is the first study showing that 2,3butanediol controls plant viral diseases and the plant's immune response is dependent on the presence of specific 2,3-butanediol isomers. The results are based on the quantification of plant 

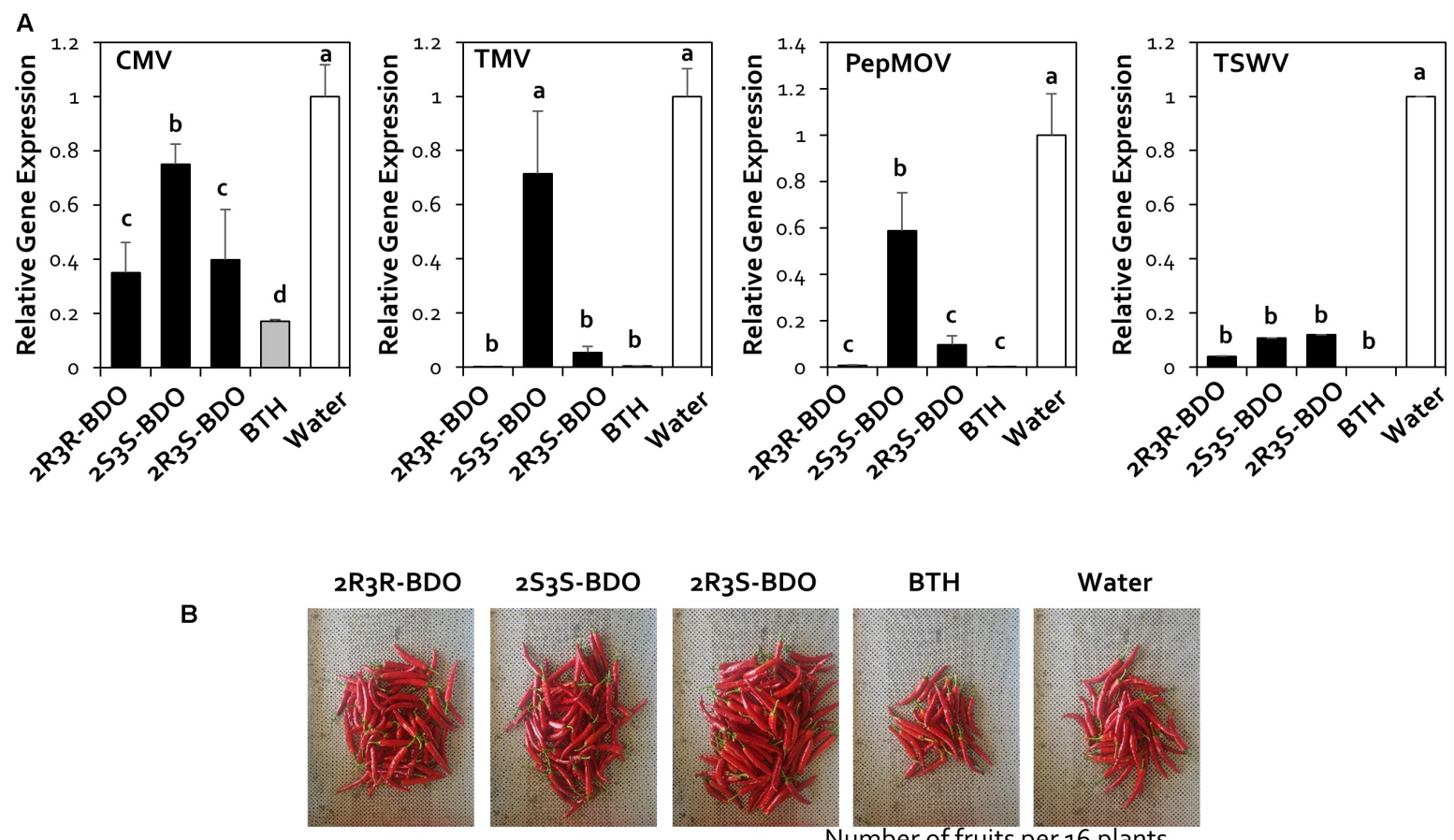

Water
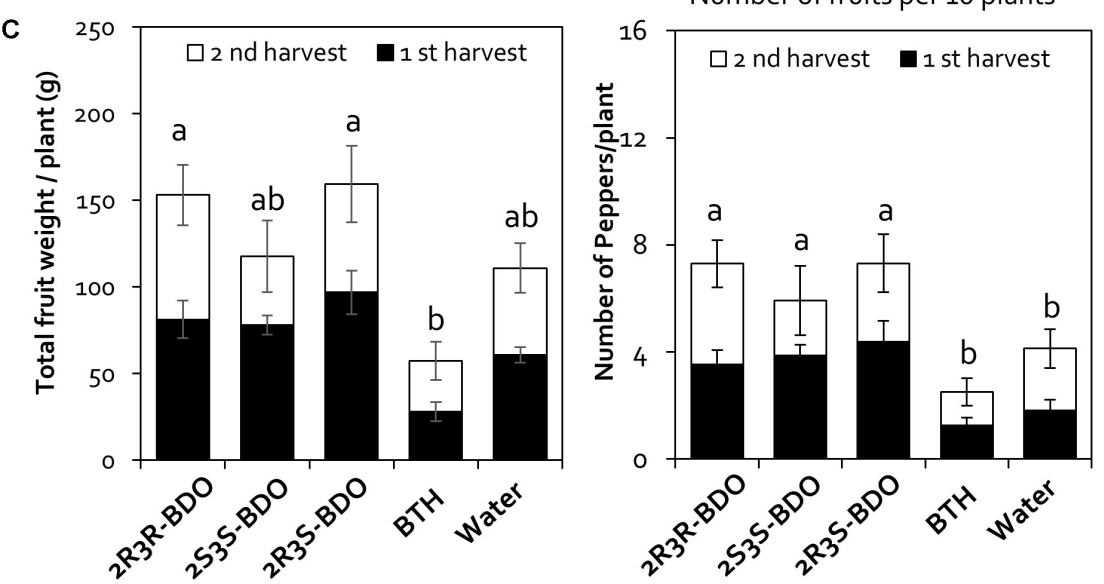

FIGURE 4 | Disease suppression of naturally occurring viruses by treatment with 2,3-butanediol (2,3-BDO) isomers. (A) Disease symptoms caused by naturally occurring viruses were evaluated at 90 days post-transplantation (dpt). (B) The induction of resistance against Cucumber mosaic virus (CMV), Tobacco mosaic virus (TMV), Pepper mottle virus (PepMoV), and Tomato spotted wilt virus (TSWV) by application of each 2,3-BDO isomer (2R,3R-, 2R,3S-, and 2S,3S-butanediol) was evaluated at $90 \mathrm{dpt}$ in the field. Bars represent mean \pm SEM $(n=100)$. The housekeeping gene CaUBQ was used as a reference in qPCR. (C) Fruit fresh weight per plant and the fruit yield of 16 plants treated with 2,3-BDO, benzothiadiazole (BTH), and water were assessed at 100 dpt. Different letters indicate statistically significant differences $(P<0.05)$. Error bars represent mean \pm SEM.

defense gene expression through qRT-PCR. Therefore, 2,3butanediol isomers can potentially be used as a bioprotectant of plants against viruses under field conditions.

Pepper fruit is an important commercial vegetable product. Viral diseases have recently been reducing the yield and quality of red peppers yearly in South Korea. Under natural field conditions, various plant viruses infect pepper, such as CMV, TMV, TSWV, PepMoV, and TYLCV. TSWV, PepMoV, and TYLCV occur sporadically, whereas CMV and TMV are the most important red pepper viruses. CMV, PepMoV, and TMV belong to group IV (viruses with positive sense single-stranded RNA); the majority of plant viruses are included in this group. TSWV belongs to group $\mathrm{V}$ (viruses with negative sense single-stranded RNA), and TYLCV belongs to group II (viruses with singlestranded DNA). In field experiments, different viral diseases may occur depending on the abiotic conditions (topography, climate, and soil type). Plant viruses depend on insect vectors for their survival, transmission, and spread. Consequently, changes in insect vectors affect the occurrence of viral diseases.

The effectiveness of many bacteria in controlling viral diseases has been demonstrated (Ryu et al., 2004; Dashti et al., 2012). We recently evaluated the effects of leaf-colonizing 

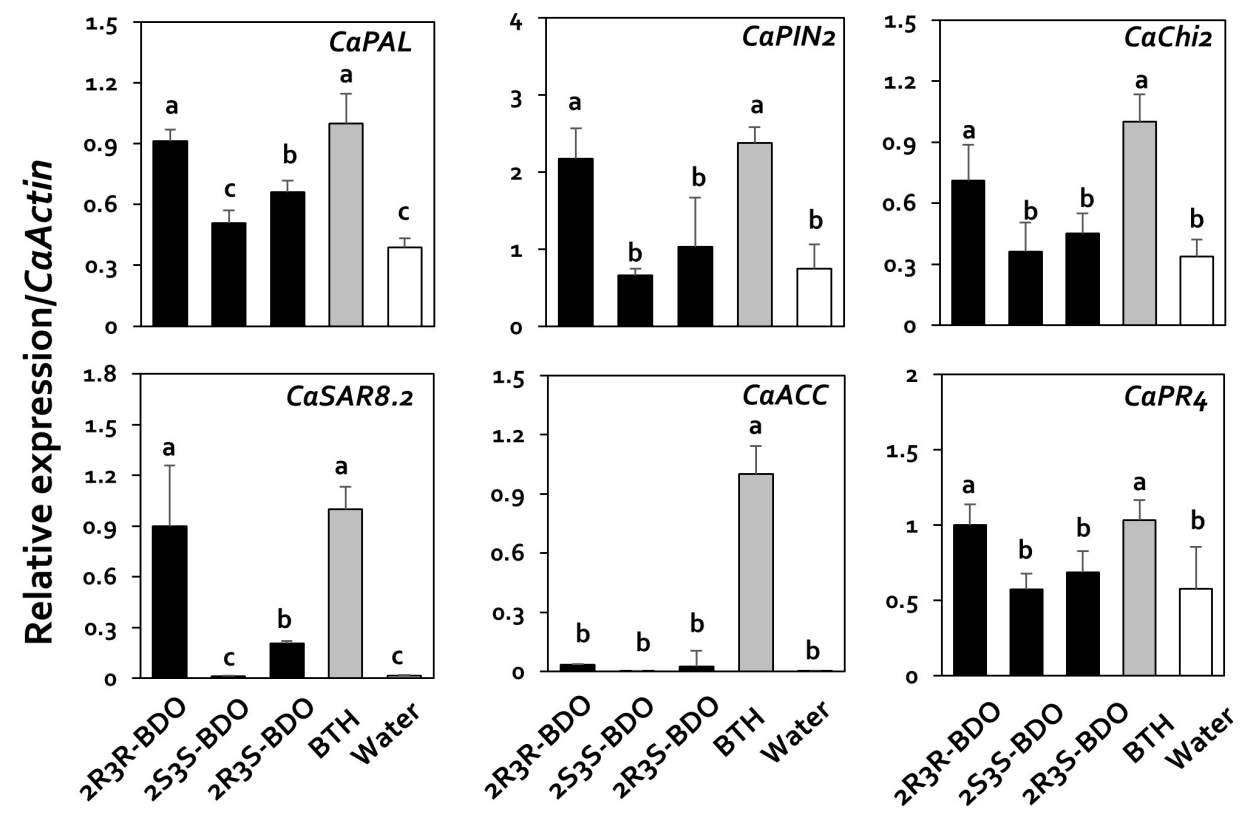

FIGURE 5 | Induction of pepper defense-related gene expression by 2,3-butanediol isomers under field conditions. Quantification of the expression of marker genes of the salicylic acid (CaPAL, CaPR4, and CaSAR8.2), ethylene (CaACC), and jasmonic acid (CaPIN2, CaPR4, and CaChi2) signaling pathways in plants treated with $1 \mathrm{mM}$ of each 2,3-butanediol isomer (2R,3R-, 2R,3S-, and 2S,3S-butanediol), $1 \mathrm{mM}$ benzothiadiazole (BTH), and water. The housekeeping gene CaActin was used for normalization. Different letters within panels indicate significant differences between treatments according to LSD at a significance level of $P<0.05$. Error bars represent mean \pm SEM. Sample size: $n=100$ plants per treatment in 2017.

B. amyloliquefaciens strain 5B6 in protecting crop plants against CMV in pepper (Lee and Ryu, 2016). Although bacterial isolates are effective in controlling viral diseases, their application in the field is limited due to the decreased survival and activity of introduced bacteria in the natural environment (Vejan et al., 2016). Therefore, the inhibition of plant viral diseases using active substances produced by bacteria has been proposed, and BVCs released from bacteria have been shown to promote growth and induce defense responses in the host plant (Bailly and Weisskopf, 2012; Yi et al., 2016). However, the effect of 2,3-butanediol on plant viral disease has not previously been elucidated. In this study, we investigated the effects of soil application of 2,3-butanediol on protecting plants from various viruses. We determined the optimal concentration of 2,3-butanediol for field application through analysis in the greenhouse and monitored the reduction in virus levels in the field. The qRT-PCR assay showed that viral accumulation continuously decreased in 2,3-butanediol-treated plants in both the greenhouse and field (Figures 1, 2). The levels of TYLCV, TSWV, and PepMoV also decreased under 2,3-butanediol treatment, suggesting that 2,3-butanediol could be used as a commercial formulation for the biological control of viral diseases.

The direct inhibition of virus accumulation in plants by 2,3-butanediol treatment might be due to its effect on the induction of ISR in plants. Indeed, the inhibition of viral disease through induced resistance mediated by bacteria and bacterial metabolites in plants has been reported (Murphy et al., 2003). The effect of 2,3-butanediol treatment appears to be dependent on SA, JA, and ET for ISR induction under field conditions (Figure 3).
These results suggest that the reduction in viral infection by 2,3-butanediol treatment is not due to its antiviral effect against viruses but is instead due to its direct effect on increasing plant resistance to overall viral diseases through the induction of plant immunity. Similarly, the direct effect of 2,3-butanediol on pepper roots was reflected by increases in plant defense gene expression. Indeed, CaPAL, CaSAR8.2, CaACC, and CaPR2 were previously shown to be upregulated in plants whose roots were drenched with 2,3-butanediol (Yi et al., 2016). However, 2,3-butanediol has not previously been shown to protect plants from viral diseases, although treatment with the bacterial volatile derivative 3-pentanol was found to mitigate the severity of disease in pepper caused by Xanthomonas axonopodis and naturally occurring CMV. RT-PCR analysis showed that this treatment increased the expression of defense-related genes involved in the SA, JA, and ET signaling pathways (Choi et al., 2014). The suppression of plant viral diseases by both 2,3-butanediol and 3-pentanol treatment suggests that additional BVCs with this effect might also be discovered.

All three isomeric forms of 2,3-butanediol are reportedly produced by specific types of bacteria. Therefore, using field experiments, we confirmed that the plant defense response against plant viruses likely occurs in an isomer-dependent manner. Specifically, in plants treated with the $\mathrm{R}$ form and meso form of 2,3-butanediol, the accumulation of viruses continuously decreased, as was observed in the other field experiment using mixed isomers (Figure 4). However, in plants treated with the $S$ form of this compound, there was no significant difference in viral levels compared with the control. 
The mechanism underlying the induction of plant resistance by specific 2,3-butanediol isomers is unclear. Furthermore, we examined the expression levels of CaPR4, CaPIN2, CaPAL, CaACC, CaSAR8.2, and CaChi2 to directly determine the effects of the 2,3-butanediol isomers on inducing plant immunity. We found that plant defense-related genes were induced only by 2R,3R-butanediol (Figure 5). Indeed, the stereochemistry of 2R,3R-butanediol is important for ISR in tobacco to Erwinia carotovora subsp. carotovora SCC1, as 2S,3S-butanediol did not activate plant resistance to this pathogen (Han et al., 2006). These findings suggest that the induction levels of plant defense responses differ depending on the isomers of the BVCs utilized.

The isomer-dependent activity of 2,3-butanediol in plants could be due to three underlying mechanisms. First, the 2,3-butanediol isomers investigated in this study are enriched in bacteria that produce similar isomers in the rhizosphere. Indeed, 2,3-butanediol is produced by various bacteria including B. amyloliquefaciens (Celińska and Grajek, 2009), Bacillus subtilis (Xiao and Xu, 2007), Enterobacter aerogenes (Byun et al., 1994), Klebsiella pneumoniae (Biebl et al., 1998), Klebsiella oxytoca (Syu, 2001), Lactococcus lactis (Hugenholtz and Starrenburg, 1992), Paenibacillus polymyxa (De Mas et al., 1988), and S. marcescens (Zhang et al., 2010). Soil bacteria and fungi synthesize the three stereoisomers (2R,3R-, 2S,3S-, and 2R,3S-) of 2,3-butanediol from pyruvate via a dehydrogenation and oxidation step (Wang et al., 2014; Kandasamy et al., 2016; Yi et al., 2016). While the exact role played by 2,3-butanediol between the bacteria and plant host is largely unknown, the production of various 2,3-butanediol isomers, depending on the bacteria, suggests that they might be used for bacterial interactions. For example, 2,3-butanediol from $B$. subtilis negatively regulates $R s m A$, encoding a posttranscriptional regulator of virulence factors, in $P$. carotovorum subsp. carotovorum (Kõiv et al., 2013; Broberg et al., 2014). Therefore, 2R,3R- and 2R,3S-butanediol, which are mainly produced by Bacillus spp., are likely enriched in Bacillus spp. producing the same isomer in the rhizosphere. Specific strains of B. amyloliquefaciens, B. subtilis, B. pasteurii, B. cereus, B. pumilus, B. mycoides, and B. sphaericus elicit significant reductions in disease levels in various hosts (Kloepper et al., 2004b). The number of whitefly nymphs that transmit Tomato mottle virus (ToMoV) was significantly reduced by treatment with B. amyloliquefaciens IN937a and B. subtilis IN937b, and significant reductions in the severity of ToMoV and in disease incidence resulted from B. subtilis IN937b and B. pumilus SE34 treatment (Murphy et al., 2000).

Second, 2,3-butanediol has direct effects on the host plant, depending on the isomer used. Treatment with 2,3-butanediol directly affects plant immunity. Treatment with the 2,3-butanediol production mutant B. subtilis failed to stimulate plant defense responses, whereas treatment with wild-type $B$. subtilis successfully induced plant defense responses against bacterial pathogens, indicating that 2,3-butanediol plays a direct role in plant immunity (Ryu et al., 2004; Rudrappa et al., 2010). The different effects of the three 2,3-butanediol isomers on pepper indicate that plants have distinct receptors for each of these isomers. Consistent with our data, only 2R,3Rbutanediol effectively improves plant growth and resistance to
P. carotovorum subsp. carotovorum in Nicotiana, suggesting that plants have specific receptors for this isomer (Han et al., 2006). BVCs from B. subtillis GB03 do not promote the growth of Arabidopsis thaliana with mutated cre1, which encodes a cytokinin receptor (Ryu et al., 2003). This suggests that plant receptors play a role in the recognition of bacterial BVCs. BVCs may be recognized by ET receptors in plants. Indeed, it has been proposed that BVCs are recognized by ETR1-like ET receptors (Bailly and Weisskopf, 2012). However, we do not have any evidence that CRE1 can physically bind to bacterial volatiles such as 2,3-butanediol. Plants recognize bacteria by detecting microbe-associated molecular patterns via membrane-localized receptor kinases. Currently, receptor signaling is best understood at the genetic level. Indeed, genetic analyses demonstrated that ET receptor signaling negatively regulates ET responses (Hua et al., 1998). Specifically, this is achieved via receptor activation of CONSTITUTIVE RESPONSE1 (CTR1) protein kinase, which represses ET signaling mediated by ETHYLENE INSENSITIVE2 (EIN2). This mechanism was demonstrated by the findings that mutants with null mutations in multiple ET receptor genes and ctr1 loss-of-function mutations display similar ET responses, whereas those with gain-of-function receptor mutations are insensitive to ET (Hua et al., 1998). Isomer-specific receptors in plants should be investigated based on the results of this and previous plant receptor studies.

Third, 2,3-butanediol might reduce the incidence of viral diseases in plants by providing an alkaline environment that protects bacterial cells from unfavorable acidic conditions (Yoon and Mekalanos, 2006; Pradhan et al., 2010; Bari et al., 2011). In addition, this treatment increases bacterial robustness against harmful compounds, such as root exudates. Furthermore, root exudates from 2,3-butanediol-treated pepper exhibited selective antagonism against Ralstonia solanacearum. By contrast, application of 2,3-butanediol-elicited root exudate increases robustness of the PGPR Bacillus subtilis GB03 and the saprophyte Pseudomonas protegens Pf-5 (Yi et al., 2016). These findings suggest that 2,3-butanediol increases the robustness of the acidic rhizosphere environment (Hinsinger et al., 2003; Huang and Chen, 2003). The increased robustness of the bacteria may be dependent on the activities of particular 2,3-butanediol isomers, which have different effects on the induction of ISR in plants. Based on these three possible mechanisms, the effects of 2,3-butanediol on plant immune responses can be explained not only by its direct effect on rhizosphere bacteria, but also by the direct induction of plant resistance and the changes in rhizosphere conditions such as plant root exudate.

\section{CONCLUSION}

This is the first report demonstrating that 2,3-butanediol protects pepper plants from viral diseases under field conditions. In particular, through field experiments, we confirmed that different isomers of 2,3-butanediol have different effects on controlling plant viruses via the induction of plant immunity. Active compounds derived from bacteria (such as 2,3-butanediol) could be highly valuable for industrial applications. Despite the 
efficacy of 2,3-butanediol in protecting plants from viral diseases, the limitation of formulation technology to control volatility currently poses a challenge for the commercialization of 2,3-butanediol. However, further experiments are needed to assess the mechanism underlying the induction of ISR and the effects of the rhizosphere environment on a particular 2,3-butanediol isomer.

\section{AUTHOR CONTRIBUTIONS}

C-MR designed the study. HK, TS, and TK performed all the experiments. TS and TK helped with the in vitro experiments

\section{REFERENCES}

Agrios, G. N. (2005). Plant Pathology. New York, NY: Academic Press.

Bailly, A., and Weisskopf, L. (2012). The modulating effect of bacterial volatiles on plant growth : current knowledge and future challenges. Plant Signal. Behav. 7, 79-85. doi: 10.4161/psb.7.1.18418

Bari, W., Song, Y. J., and Yoon, S. S. (2011). Suppressed induction of proinflammatory cytokines bya unique metabolite produced by Vibrio cholerae O1 EI Tor biotype in cultured host cell. Infect. Immun. 79, 3149-3158. doi: 10.1128/IAI.01237-10

Barrett, E., Collins, E., Hall, B., and Matoi, S. (1983). Production of 2,3-butylene glycol from whey by Klebsiella pneumoniae and Enterobacter aerogenes. J. Dairy Sci. 66, 2507-2514. doi: 10.3168/jds.S0022-0302(83)82119-5

Biebl, H., Zeng, A.-P., and Deckwer, W.-D. (1998). Fermentation of glycerol to 1,3-propanediol and 2,3-butanediol by Klebsiella pneumoniae. Appl. Microbiol. Biotechnol. 50, 24-29. doi: 10.1007/s002530051251

Broberg, M., Lee, G. W., Nykyri, J., Lee, Y. H., Pirhonen, M., and Palva, E. T. (2014). The global response regulator ExpA controls virulence gene expression through RsmA-mediated and RsmA-independent pathways in Pectobacterium wasabiae SCC3193. Appl. Environ. Microbiol. 80, 1972-1984. doi: 10.1128/AEM. 03829-13

Byun, T.-G., Zeng, A.-P., and Deckwer, W.-D. (1994). Reactor comparison and scale-up for the microaerobic production of 2,3-butanediol by Enterobacter aerogenes at constant oxygen transfer rate. Bioprocess Eng. 11, 167-175. doi: 10.1007/BF00518739

Celińska, E., and Grajek, W. (2009). Biotechnological production of 2,3butanediol-Current state and prospects. Biotechnol. Adv. 27, 715-725. doi: 10.1016/j.biotechadv.2009.05.002

Choi, H. K., Song, G. C., Yi, H. S., and Ryu, C.-M. (2014). Field evaluation of the bacterial volatile derivative 3-pentanol in priming for induced resistance in pepper. J. Chem. Ecol. 40, 882-892. doi: 10.1007/s10886-0140488-z

D’Alessandro, M. D., Erb, M., Ton, J., Brandenburg, A., Karlen, D., Zopfi, J., et al. (2014). Volatiles produced by soil-borne endophytic bacteria increase plant pathogen resistance and affect tritrophic interactions. Plant Cell Environ. 37, 813-826. doi: 10.1111/pce.12220

Dashti, N. H., Ali, N. Y., Cherian, V. M., and Montasser, M. S. (2012). Application of plant growth-promoting rhizobacteria (PGPR) in combination with a mild strain of Cucumber mosaic virus (CMV) associated with viral satellite RNAs to enhance growth and protection against a virulent strain of CMV in tomato. Can. J. Plant Pathol. 34, 177-186. doi: 10.1080/07060661.2012. 685495

De Mas, C., Jansen, N. B., and Tsao, G. T. (1988). Production of optically active 2,3butanediol by Bacillus polymyxa. Biotechnol. Bioeng. 31, 366-377. doi: 10.1002/ bit. 260310413

Duijff, B. J., Gianinazzi-Pearson, V., and Lemanceau, P. (1997). Involvement of the outer membrane lipopolysaccharides in the endophytic colonization of tomato roots by biocontrol Pseudomonas fluorescens strain WCS417r. New Phytol. 135, 325-334. doi: 10.1046/j.1469-8137.1997.00646.x

Guerret, M. G. L., Barvetti, M. J., You, M. P., and Jones, A. C. (2016). Effects of temperature on disease severity in plants of subterranean clover and in vivo treatments. C-MR contributed to scientific discussions that guided the project. C-MR and HK wrote the paper.

\section{FUNDING}

This research was partially supported by the grants from Farm Hannong Co., Ltd., the Korea Research Institute of Bioscience and Biotechnology (KRIBB) Initiative Program of South Korea. This work was also supported by the grant from the Agenda Project (Agenda Project No. PJ012814022018) of the Rural Development Administration, South Korea.

infected singly or in mixed infection with Bean yellow mosaic virus and Kabatiella caulivora. J. Phytopathol. 164, 608-619. doi: 10.1111/jph. 12484

Gupta, B., Hashim, M., Ramachandran, K., Sen Gupta, I., and Cui, Z. (2005). The effect of gas sparging in cross flow microfiltration of 2, 3 butanediol fermentation broth. Eng. Life Sci. 5, 54-57. doi: 10.1002/elsc.2004 00054

Han, S. H., Lee, S. J., Moon, J. H., Park, K. H., Yang, K. Y., Cho, B. H., et al. (2006). GacS-dependent production of 2R,3R-butanediol by Pseudomonas chlororaphis $\mathrm{O} 6$ is a major determinant for eliciting systemic resistance against Erwinia carotovora but not against Pseudomonas syringae pv. tabaci in tobacco. Mol. Plant Microbe Interact. 19, 924-930. doi: 10.1094/MPMI-190924

Hashimoto, M., Neriya, Y., Yamaji, Y., and Namba, S. (2016). Recessive resistance to plant viruses: potential resistance genes beyond translation initiation factors. Front. Microbiol. 7:1695. doi: 10.3389/fmicb.2016. 01695

Herold, B., Pfeiffer, P., and Radier, F. (1995). Determination of the three isomers of 2,3-Butanediol formed by yeasts or lactic acid bacteria during fermentation. Am. J. Enol. Vitic. 46, 134-137.

Hinsinger, P., Plassard, C., Tang, C., and Jaillard, B. (2003). Origins of root-mediated $\mathrm{pH}$ changes in the rhizosphere and their responses to environmental constraints. Plant Soil 248, 43-59. doi: 10.1023/A:10223711 30939

Hua, J., Sakai, H., Nourizadeh, S., Chen, Q. G., Bleecker, A. B., Ecker, J. R., et al. (1998). EIN4 and ERS2 are members of the putative ethylene receptor gene family in Arabidopsis. Plant Cell 10, 1321-1332. doi: 10.1105/tpc.10.8.1321

Huang, J. W., and Chen, J. (2003). "Role of pH in phytoremediation of contaminated soils," in Handbook of Soil Acidity, ed. Z. Rengel (New York, NY: Marcel Dekker), 449-472. doi: 10.1201/97802039123 17.ch17

Hugenholtz, J., and Starrenburg, M. J. C. (1992). Diacetyl production by different strains of Lactococcus lactis subsp. lactis var. diacetylactis and Leuconostoc spp. Appl. Microbiol. Biotechnol. 38, 17-22. doi: 10.1007/BF0016 9412

Ji, X.-J., Huang, H., and Ouyang, P.-K. (2011). Microbial 2,3-butanediol production: a state-of-the-art review. Biotechnol. Adv. 29, 351-364. doi: 10. 1016/j.biotechadv.2011.01.007

Jones, R. A. (2017). Future scenarios for plant virus pathogens as climate change progresses. Adv. Virus Res. 95, 87-140. doi: 10.1016/bs.aivir.2016. 02.004

Kai, M., Haustein, M., Molina, F., Petri, A., Scholz, B., and Piechulla, B. (2009). Bacterial volatiles and their action potential. Appl. Microbiol. Biotechnol. 81, 1001-1012. doi: 10.1007/s00253-008-1760-3

Kandasamy, V., Liu, J., Dantoft, S. H., Solem, C., and Jensen, P. R. (2016). Synthesis of (3R)-acetoin and 2,3-butanediol isomers by metabolically engineered Lactococcus lactis. Sci. Rep. 6:36769. doi: 10.1038/srep 36769

Kang, B. C., Yeam, I., and Jahn, M. M. (2005). Genetics of plant virus resistance. Annu. Rev. Phytopathol. 43, 581-621. doi: 10.1146/annurev.phyto.43.011205. 141140 
Kesselmeier, J., and Staudt, M. (1999). Biogenic volatile organic compounds (VOC): an overview on emission, physiology and ecology. J. Atmos. Chem. 33, 23-88. doi: 10.1023/A:1006127516791

Khalid, A., Zhang, Q., Yasir, M., and Li, F. (2017). Small RNA based genetic engineering for plant viral resistance: application in crop protection. Front. Microbiol. 8:43. doi: 10.3389/fmicb.2017.00043

Kloepper, J. W., Reddy, M. S., Rodríguez-Kabana, R., Kenney, D. S., KokalisBurelle, N., and Martinez-Ochoa, N. (2004a). Application for rhizobacteria in transplant production and yield enhancement. Acta Hortic. 631, 219-229. doi: 10.17660/ActaHortic.2004.631.28

Kloepper, J. W., Ryu, C.-M., and Zhang, S. (2004b). Induced systemic resistance and promotion of plant growth by Bacillus spp. Phytopathology 94, 1259-1266. doi: 10.1094/PHYTO.2004.94.11.1259

Kõiv, V., Andresen, L., Broberg, M., Frolova, J., Somervuo, P., Auvinen, P., et al. (2013). Lack of RsmA-mediated control results in constant hypervirulence, cell elongation, and hyperflagellation in Pectobacterium wasabiae. PLoS One 8:e54248. doi: 10.1371/journal.pone.0054248

Kopke, M., Mihalcea, C., Liew, F. M., Tizard, J. H., Ali, M. S., Conolly, J. J., et al. (2011). 2,3-Butanediol production by acetogenic bacteria, an alternative route to chemical synthesis, using industrial waste gas. Appl. Environ. Microbiol. 77, 5467-5475. doi: 10.1128/AEM.00355-11

Lamberth, C., Jeanmart, S., Luksch, T., and Plant, A. (2013). Current challenges and trends in the discovery of agrochemicals. Science 341, 742-746. doi: 10.1126/ science. 1237227

Lee, G. H., Lee, S.-H., Kim, K. M., and Ryu, C.-M. (2017). Foliar application of the leaf colonizing yeast Pseudozyma churashimaensis elicits systemic defense of pepper against bacterial and viral pathogens. Sci. Rep. 7:39432. doi: 10.1038/ srep39432

Lee, G. H., and Ryu, C.-M. (2016). Spraying of leaf-colonizing Bacillus amyloliquefaciens protects pepper from Cucumber mosaic virus. Plant Dis. 100, 2099-2105. doi: 10.1094/PDIS-03-16-0314-RE

Leeman, M., Van Pelt, J. A., Den Ouden, F. M., Heinsbroek, M., Bakker, P. A., and Schippers, B. (1995). Induction of systemic resistance against fusarium wilt of radish by lipopolysaccharides of Pseudomonas fluorescens. Phytopathology 85, 1021-1027. doi: 10.1094/Phyto-85-1021

Mandadi, K. K., and Scholthof, K. B. (2013). Plant immune responses against viruses: how does a virus cause disease? Plant Cell 25, 1489-1505. doi: 10.1105/ tpc.113.111658

Maurhofer, M., Hase, C., Meuwly, P., Metraux, J. P., and Defago, G. (1994). Induction of systemic resistance of tobacco necrosis virus by the rootcolonizing Pseudomonas fluorescens strain CHAO: influence of the gacA Gene and of pyoverdine production. Phytopathology 84, 139-146. doi: 10.1094/ Phyto-84-139

Murphy, J. F., Reddy, M. S., Ryu, C. M., Kloepper, J. W., and Li, R. (2003). Rhizobacteria mediated growth promotion of tomato leads to protection against Cucumber mosaic virus. Phytopathology 93, 1301-1307. doi: 10.1094/ PHYTO.2003.93.10.1301

Murphy, J. F., Zehnder, G. W., Schuster, D. J., Sikora, E. J., Polston, J. E., and Kloepper, J. W. (2000). Plant growth-promoting rhizobacterial mediated protection in tomato against Tomato mottle virus. Plant Dis. 84, 779-784. doi: 10.1094/PDIS.2000.84.7.779

Ongena, M., Jourdan, E., Schäfer, M., Kech, C., Budzikiewicz, H., Luxen, A., et al. (2005). Isolation of an $\mathrm{N}$-alkylated benzylamine derivative from Pseudomonas putida BTP1 as elicitor of induced systemic resistance in bean. Mol. Plant Microbe. Interact. 18, 562-569. doi: 10.1094/MPMI-180562

Perring, T. M., Gruenhagen, N. N., and Farrar, C. A. (1999). Management of plant viral diseases through chemical control of insect vectors. Annu. Rev. Entomol. 44, 457-481. doi: 10.1146/annurev.ento.44.1.457

Pradhan, S., Baidya, A. K., Ghosh, A., Paul, K., and Chowdhury, R. (2010). The EI Tor biotype of Vibrio cholerae exhibits a growth advantage in the stationary phase in mixed cultures with the classical biotype. J. Bacteriol. 192, 955-963. doi: 10.1128/JB.01180-09

Raupach, G. S., Liu, L., Murphy, J. F., Tuzun, S., and Kloepper, J. W. (1996). Induced systemic resistance in cucumber and tomato against Cucumber mosaic cucumovirus using plant growth-promoting rhizobacteria (PGPR). Plant Dis. 80, 891-894. doi: 10.1094/PD-80-0891
Ross, A. F. (1961). Systemic acquired resistance induced by localized virus infections in plants. Virology 14, 340-358. doi: 10.1016/0042-6822(61)90 319-1

Rudrappa, T., Biedrzycki, M. L., Kunjeti, S. G., Donofrio, N. M., Czymmek, K. J., Paul, P., et al. (2010). The rhizobacterial elicitor acetoin induces systemic resistance in Arabidopsis thaliana. Commun. Integr. Biol. 3, 130-138. doi: $10.4161 /$ cib.3.2.10584

Ryals, J., Kessmann, H., Staub, T., Hofmann, C., Maetzke, T., and Herzog, J. (1994). Induction of systemic acquired disease resistance in plants by chemicals. Annu. Rev. Phytopathol. 32, 439-459. doi: 10.1146/annurev.py.32.090194. 002255

Ryu, C.-M., Choi, H. K., Lee, C. H., Murphy, J. F., Lee, J. K., and Kloepper, J. W. (2013). Modulation of quorum sensing in acyl-homoserine lactoneproducing or -degrading tobacco plants leads to alteration of induced systemic resistance elicited by the rhizobacterium Serratia marcescens 90-166. Plant Pathol. J. 29, 224-230. doi: 10.5423/PPJ.SI.11.2012. 0173.R2

Ryu, C.-M., Farag, M. A., Hu, C. H., Reddy, M. S., Kloepper, J. W., and Pare, P. W. (2004). Bacterial volatiles induce systemic resistance in Arabidopsis. Plant Physiol. 134, 1017-1026. doi: 10.1104/pp.103. 026583

Ryu, C.-M., Farag, M. A., Hu, C. H., Reddy, M. S., Wei, H. X., Pare, P. W., et al. (2003). Bacterial volatiles promote growth in Arabidopsis. Proc. Natl. Acad. Sci. U.S.A. 100, 4927-4932. doi: 10.1073/pnas.07308 45100

Song, G. C., Choi, H. K., and Ryu, C.-M. (2013). The folate precursor paraaminobenzoic acid elicits induced resistance against Cucumber mosaic virus and Xanthomonas axonopodis. Ann. Bot. 111, 925-934. doi: 10.1093/aob/ mct049

Strange, R. N., and Scott, P. R. (2005). Plant disease: a threat to global food security. Annu. Rev. Phytopathol. 43, 83-116. doi: 10.1146/annurev.phyto.43. 113004.133839

Syu, M.-J. (2001). Biological production of 2,3-butanediol. Appl. Microbiol. Biotechnol. 55, 10-18. doi: 10.1007/s002530000486

Tally, A., Oostensdorp, M., Lawton, K., Staub, T., and Bassi, B. (1999). “Commercial development of elicitors of induced resistance to pathogens," in Induced Plant Defenses Against Pathogens and Herbivores, eds A. Agrawal, S. Tuzun, and E. Bent (St. Paul, MN: APS Press), 357-369.

Valkonen, J. P. T. (2015). Elucidation of virus-host interactions to enhance resistance breeding for control of virus diseases in potato. Breed. Sci. 65, 69-76. doi: $10.1270 /$ jsbbs. 65.69

Vejan, P., Abdullah, R., Khadiran, T., Ismail, S., and Nasrulhaq Boyce, A. (2016). Role of plant growth promoting rhizobacteria in agricultural sustainability-A Review. Molecules 21:573. doi: 10.3390/molecules210 50573

Voloch, M., Jansen, N. B., Ladisch, M. R., Tsao, G. T., Narayan, R., and Rodwell, V. W. (1985). 2,3-Butanediol. Oxford: Pergamon Press.

Wang, Z., Song, Q., Yu, M., Wang, Y., Xiong, B., Zhang, Y., et al. (2014). Characterization of a stereospecific acetoin (diacetyl) reductase from Rhodococcus erythropolis WZ010 and its application for the synthesis of $(2 \mathrm{~S}, 3 \mathrm{~S})$ 2,3-butanediol. Appl. Microbiol. Biotechnol. 98, 641-650. doi: 10.1007/s00253013-4870-5

Xiao, Z., and Xu, P. (2007). Acetoin metabolism in bacteria. Crit. Rev. Microbiol. 33, 127-140. doi: 10.1080/10408410701364604

Yang, J. W., Yi, H. S., Kim, H., Lee, B. Y., Lee, S. H., Ghim, S. Y., et al. (2011). Whitefly infestation of pepper plants elicits defence responses against bacterial pathogens in leaves and roots and changes the belowground microflora. J. Ecol. 99, 46-56. doi: 10.1111/j.1365-2745.2010. 01756.x

Yang, J. W., Yu, S. H., and Ryu, C.-M. (2009). Priming of defense-related genes confers root-colonizing bacilli-elicited induced systemic resistance in pepper. Plant Pathol. J. 25, 389-399. doi: 10.5423/PPJ.2009.25. 4.389

Yi, H.-S., Ahn, Y.-R., Song, G. C., Ghim, S.-Y., Lee, S. H., Lee, G. H., et al. (2016). Impact of a bacterial volatile 2,3-Butanediol on Bacillus subtilis Rhizosphere Robustness. Front. Microbiol. 7:993. doi: 10.3389/fmicb.2016. 00993 
Yoon, S. S., and Mekalanos, J. J. (2006). 2,3-butanediol synthesis and the emergence of the Vibrio cholerae El Tor biotype. Infect. Immun. 74, 6547-6556. doi: 10.1128/IAI.00695-06

Zehnder, G. W., Murphy, J. F., Sikora, E. J., and Kloepper, J. W. (2001). Application of rhizobacteria for induced resistance. Euro. J. Plant Pathol. 107, 39-50. doi: 10.1023/A:1008732400383

Zehnder, G. W., Yao, C., Murphy, J. F., Sikora, E. J., and Kloepper, J. W. (2000). Induction of resistance in tomato against cucumber mosaic cucumovirus by plant growth-promoting rhizobacteria. BioControl 45, 127-137. doi: 10.1023/A: 1009923702103

Zhang, L., Yang, Y., Sun, J., Shen, Y., Wei, D., Zhu, J., et al. (2010). Microbial production of 2,3-butanediol by a mutagenized strain of Serratia marcescens H30. Bioresour. Technol. 101, 1961-1967. doi: 10.1016/j.biortech.2009.10.052
Conflict of Interest Statement: TS and TK are employed by Farm Hannong Co., Ltd. (South Korea).

The other authors declare that the research was conducted in the absence of any commercial or financial relationships that could be construed as a potential conflict of interest.

Copyright (C) 2018 Kong, Shin, Kim and Ryu. This is an open-access article distributed under the terms of the Creative Commons Attribution License (CC BY). The use, distribution or reproduction in other forums is permitted, provided the original author(s) and the copyright owner are credited and that the original publication in this journal is cited, in accordance with accepted academic practice. No use, distribution or reproduction is permitted which does not comply with these terms. 